\title{
Iwan Czistiakow, Strażnik Gutagu. Dziennik, tlum. Jan Cichocki, Bellona, Warszawa 2012, 301 stron
}

Międzynarodowe Stowarzyszenie Memoriał (utworzone w 1988 r., pierwszym przewodniczącym był Andriej Sacharow) to instytucja wielce zasłużona w dziedzinie badawczej, edukacyjnej, obrony praw człowieka, w szczególności zaś odkłamywania mrocznej historii ZSRR. My, Polacy, wiele Memoriałowi zawdzięczamy w żmudnej pracy nad ustalaniem zbrodni komunistycznych dokonywanych na Polakach i obywatelach polskich. Stowarzyszenie Memoriał miało szczęście pozyskać niebywały dokument: dziennik pisany przez strażnika GUŁagu. Nawet nie wspomnienia, lecz dziennik pisany na bieżąco, w dniach owej podłej służby strażnika nieszczęsnych łagierników budujących Bajkalsko-Amurską Magistralę Kolejową (BAM) w syberyjskich warunkach. Wydany w 2008 r. w Rosji, w polskim przekładzie ukazał się w cztery lata później. Warto dodać, że wydanie jest naukowo staranne, umiarkowanie opatrzone stosownymi przypisami wyjaśniającymi czytelnikowi zarówno niektóre realia stalinowskiej rzeczywistości, jak też np. łagierniczego slangu. Książka zawiera dwie wkładki fotograficzne ściśle dotyczące budowy BAM-u przez więźniów, przede wszystkim zaś zawiera kompletną reprodukcję dwóch zeszytów zapisanych przez Iwana Czistiakowa; autor także dużo rysował. Wydawcy dołączyli do pamiętników coś niemieszczącego się w nadanym tytule, mianowicie pochodzące $\mathrm{z}$ tego samego okresu listy zeka Afanasjewa, młodego łagiernika, wysyłane do rodziny (matki, ojca) z rozmaitych obozów Dalekiej Północy archipelagu GUŁag. W zamyśle wydawców - jak to interpretuje tłumacz - listy zeka "są wyrazistym dopełnieniem historii opowiedzianej przez strażnika łagrów na BAM - widzianej jakby z drugiej strony lustra, ale zaskakująco podobne w treści i nastroju do obozowej codzienności" (s. 233, przypis tłumacza).

Wydany dokument - pamiętnik Czistiakowa - poprzedzony został wprowadzeniem Iriny Scherbakowej, znakomitej znawczyni tamtych czasów, a zwłaszcza archipelagu GUłag. Irina Scherbakowa m.in. pisze: „To cud, że dziennik Czistiakowa, w którym zapiski urwały się prawdopodobnie wraz z jego aresztowaniem, w jakiś sposób się zachował, nie wpadł w ręce funkcjonariuszy NKWD, nie został wyrzucony i zniszczony, że udało się go przesłać do Moskwy. Dzięki temu dotarł do nas jeszcze jeden głos człowieka, który żył w strasznej epoce"1.

1 I. Scherbakowa, "W dzienniku jest moje życie...", [tak zatytułowany jest wstęp do:] I. Czistiakow, Strażnik Gułagu. Dziennik, tłum. J. Cichocki, Warszawa 2012, s. 32. 
Co wiemy o autorze pamiętnika? Bardzo niewiele, bo informacje o osobie Czistiakowa można zaczerpnąć niemal wyłącznie z jego dziennika (plus niewyraźna amatorska fotografia $\mathrm{z}$ napisem na odwrocie: Czistiakow Iwan Pietrowicz, represjonowany w latach 1937-1938. Poległ w 1941 roku na froncie w obwodzie tulskim). W dzienniku zaś Czistiakow pisze o sobie bardzo niewiele. Jako strażnik GUŁagu służył w latach 1935-1936: zaczynał w październiku 1935 r., jak na ironię, w mieście o nazwie Swobodny. I też jak na ironię, rozpoczął służbę pilnowania niewolników w czasie, gdy Stalin obwieszczał, że socjalizm został już zbudowany, co $\mathrm{w}$ roku następnym $\mathrm{w}$ pierwszym artykule triumfalnie ogłaszała światu nowa konstytucja, zwana stalinowską. Nie wiemy nawet, ile autor miał wówczas lat, ale pewnie był najwyżej w średnim wieku (może około 30?), bo raz się wyraża w swoim dzienniku, że pół życia ma za sobą. Był człowiekiem w miarę wykształconym, prawdopodobnie $\mathrm{w}$ kierunku technicznym; $\mathrm{w}$ pamiętniku odnotował, że jeden $\mathrm{z}$ pomocników do spraw zatrudnienia zadał mu pytanie: „Czemu wy, człowiek z wyższym wykształceniem, służycie w ochronie jako dowódca plutonu?" (s. 209). Mieszkał w Moskwie, w chwili przymusowego wysłania na BAM był bezpartyjny; został wydalony z partii prawdopodobnie na przełomie lat dwudziestych i trzydziestych. W pamiętniku jest wojskowym, ale sam wyraźnie pisze, że nie jest czekistą, czyli jest wojskowym Armii Czerwonej (RKKA). Z pewnością zgodnie z ustawą z $1930 \mathrm{r}$. o obowiązkowej służbie wojskowej został przymusowo wcielony i przekazany do odbycia służby w wojskach wewnętrznych NKWD jako strażnik GUŁagu. Pełnił niską funkcję dowódcy plutonu; wszak był wśród NKWD-zistów obcy, klasowo obcy, wydalony z partii. W Moskwie, za którą stale tęsknił, żył jak przeciętny inteligent: „[...] byłem w Moskwie. Żyłem. Brałem życie, a tutaj? Tutaj nie ma czego brać. Wysokości nieba się nie zrozumie, a nieskończoności sopek i pustki nie uchwyci. Za sopką sopka, za sopką sopka i tak przez tysiąc kilometrów. Dziko i bez pojęcia. Życie staje się nędzne i niepotrzebne. Moskwa! Moskwa! Jaka odległa i nieosiągalna. [...] Jaki i mały i mizerny jest człowiek w świecie $[\ldots]^{\prime \prime}$ (s. 37-38).

W jakim służył łagrze owego gigantycznego archipelagu GUŁag?

Jak wiadomo, obozy/łagry zaczęły być wykorzystywane przez bolszewików już od lata 1918 r., a dysponowano wówczas ogromnymi jednostkami, w których uprzednio trzymano jeńców wojennych ${ }^{2}$ (pamiętać warto, że dla

2 M. Jacobson, M. Smirnow, System miejsc uwięzienia w RFSRR i ZSRR w latach 1917-1930, [w:] Łagry. Przewodnik encyklopedyczny, red. N. Ochotin, A. Rogiński, tłum. R. Niedzielko, Państwowe Archiwum Federacji Rosyjskiej, Ośrodek KARTA, Warszawa 1998, s. 12; A. Applebaum, Gułag, tłum. J. Urbański, Warszawa 2005, s. 40; N. Werth, [w:] Czekiści. Organy bezpieczeństwa w europejskich krajach bloku sowieckiego 1944-1989, red. K. Persak, Ł. Kamiński, Warszawa 2010, s. 22; S. Ciesielski, GUŁag. Radzieckie obozy koncentracyjne 1918-1953, Warszawa 2010, s. 56 i passim; A. Lityński, Prawo Rosji i ZSRR 1917-1991 czyli historia wszechzwiązkowego komunistycznego prawa (bolszewików). 
Rosji wojna skończyła się separatystycznym traktatem brzeskim już 3 marca 1918 r.). Wykorzystywanie więźniów do prac jest stare jak świat. Jednak w warunkach Nowej Ekonomicznej Polityki (NEP) produkty wytwarzane w lagrach powinny być konkurencyjne na rynku, a tak nie było głównie z powodu rażąco wysokiego odsetka braków; jakość wyrobów była niska, nie udawało się uzyskiwać opłacalności. Więźniów wykorzystywano głównie przy wyrębie lasów (drewno na opał miast). Ale pod koniec lat dwudziestych Stalin zlikwidował NEP i przeprowadził rozkułaczanie, a potem kolektywizację wsi. Konsekwencją była niewyobrażalna klęska głodu. W 1929 r. przyjęto do realizacji (od 1928 r.!) plan pięcioletni (1928-1932), który postanowiono wykonać w cztery lata. Wówczas to na szerszą skalę przystąpiono do realizacji wcześniejszych koncepcji wykorzystania pracy więźniów. Rada Komisarzy Ludowych podjęła (11 lipca 1929 r.) uchwałę określającą na dziesiątki lat kierunek rozwoju systemu miejsc uwięzienia i wykorzystywania więźniów: o wykorzystaniu pracy więźniów przy kolonizacji odległych rejonów ZSRR i eksploatacji tamtejszych bogactw naturalnych. „W celu skolonizowania” odległych rejonów ZSRR „i eksploatacji ich bogactw naturalnych" zdecydowano o utworzeniu sieci poprawczych obozów pracy OGPU (ITŁ - исправительно-трудовой лагерь - isptrawitielno-trudowoj łagier). W uchwale RKL nie było ani słowa o reedukacji więźniów. Znamienne (i o dalekosiężnych skutkach), że zadanie to powierzono bezpiece - OGPU ${ }^{3}$ [OGPU - Zjednoczony Państwowy Zarząd Polityczny - Обединённое Государственное Политическое Управление Objedinionnoje Gosudarstwiennoje Politiczeskoje Uprawlejnije]. Uchwałą Rady Komisarzy Ludowych z 7 kwietnia 1930 r. powołany został organ kierujący systemem obozowym OGPU, a mianowicie Zarząd Obozów OGPU, w kilka miesięcy później przemianowany na Zarząd Główny Obozów OGPU = GUŁag4 .

Centralne zarządzanie OGPU łagrami sprowadzało się wówczas do zapewniania rozmaitym przedsiębiorstwom dostaw siły roboczej. Kierownictwo obozu zawierało kontrakty na oferowaną siłę roboczą. Począwszy od 1931 r., następowała ekonomiczna transformacja OGPU jako administratora łagrów: OGPU przeistoczył się z dostawcy siły roboczej w bezpośredniego, samodziel-

Krótki kurs, wyd. 2, Warszawa 2012, s. 377; idem, Administrowanie praca przymusowa w Rosji radzieckiej i ZSRR, [w:] Aktualne zagadnienia prawa pracy i polityki socjalnej (zbiór studiów), t. 1, red. B. M. Ćwiertnia, Sosnowiec 2012, s. 354 i passim.

3 A. Lityński, Administrowanie praca przymusową..., s. 357; idem, Prawo Rosji i ZSRR 1917-1991..., wyd. 2, s. 378.

4 Pełna nazwa brzmiała: Zarząd Główny Poprawczych Obozów i Kolonii Pracy $=$ Главное Управленийе Исправительно-Трудовой Аагерьей и Колоний - Gławnoje Uprawlenije Isprawitielno-Trudowych Łagierej i Kołonij = GUŁag, zaś od 27 października 1934 r. Главное ыправление исправительно-трудовых лагерей, трудовых поселений и мест заключения - Gławnoje uprawlenije isprawitielno-trudowych łagierej, trudowych posielenij i miest zakljuczenija - Zarząd Główny Poprawczych Obozów Pracy, Osiedli Pracy i Miejsc Uwięzienia. 
nego wykonawcę gospodarczych zadań planowych. Teraz zamiast rentowności (jak jeszcze niedawno w czasach NEP-u), żądano wykonywania zadań planowych, przyznając "limity” zaopatrzenia, w tym limit siły roboczej. Rozpoczęta w 1931 r. budowa Kanału Białomorsko-Bałtyckiego była pierwszym wielkim przedsięwzięciem gospodarczym, którego samodzielnym i bezpośrednim wykonawcą było OGPU. Była to ogromna budowa, będąca kolejnym przykładem nieracjonalności gospodarowania pracą więźniów. Kanał nosił imię Józefa Stalina. Oprócz wspomnianego Białomorsko-Bałtyckiego ITŁ, istniały na początku lat trzydziestych jeszcze dwa łagry-giganty: Dmitrowski ITŁ (budowa kanału Moskwa-Wołga; 196 tys. więźniów) i Bajkalsko-Amurski ITŁ (bajkalsko-amurska magistrala kolejowa dublująca kolej transsyberyjską na odcinku od Bajkału do Amuru).

Tej ostatniej budowie nadano absolutny priorytet, a to $\mathrm{w}$ związku ze zmianą sytuacji politycznej i wojskowej na Dalekim Wschodzie, zwłaszcza w Kraju Nadmorskim, wobec zajęcia (1930-1931) Mandżurii przez Japonię. Istniejąca kolej transsyberyjska była długimi odcinkami jednotorowa, a ponadto na długości ponad tysiąca kilometrów przebiegała w bezpośrednim sąsiedztwie okupowanej teraz przez Japończyków Mandżurii. Bajkalsko-Amurski ITŁ (Bamłag) stał się największym zespołem łagrów. Łącznie wymienione 3 łagry zatrudniały prawie połowę wszystkich więźniów.

Dnia 10 lipca 1934 r. dokonano ważnej reorganizacji, a mianowicie powołano ogólnozwiązkowy Ludowy Komisariat Spraw Wewnętrznych ZSRR NKWD [Народный Комиссариат Внутренных $\Delta$ ел - Narodnyj Komisariat Wnutriennych Dieł], dotychczasowe zaś OGPU (teraz: GUGB5) stało się jednym z zarządów NKWD, podobnie jak zarząd milicji, straży granicznej i in. Dnia 27 października tegoż roku wszystkie placówki penitencjarne podległe w tym momencie republikańskim resortom sprawiedliwości przekazano GUŁagowi NKWD ZSRR ${ }^{6}$, w którym utworzono Wydział Miejsc Uwięzienia. Na szczeblach republik, krajów i obwodów zarządzanie w oddanym sobie zakresie wykonywały wydziały miejsc uwięzienia lokalnych jednostek NKWD. W wyniku reorganizacji, z końcem 1934 r. wszystkie placówki uwięzienia (zakłady karne oraz areszty śledcze) znalazły się $\mathrm{w}$ resorcie spraw wewnętrznych - NKWD. Oprócz obozów przekazano GUŁagowi specprzesiedleńców (przesiedleńców specjalnych), zesłanych do określonych miejsc osiedlenia ZSRR. Byli oni zatrudniani na umowie o pracę na rozmaitych obiektach OGPU/NKWD.

5 OGPU przemianowane zostało na GUGB = Główny Zarząd Bezpieczeństwa Państwowego = Главное Управленийе Государтвенной Безопатности (Gławnoje Uprawlenije Gosudarstwiennoj Biezopastnosti) i pod tą nazwą weszło w skład NKWD.

6 Nadana wówczas Zarządowi pełna nazwa brzmiała: Zarząd Główny Poprawczych Obozów Pracy, Osiedli Pracy i Miejsc Uwięzienia = Главное Управленийе Исправительно-Трудовых Аагерьей, Трудовых Поселеий и Месть Заключения - Gławnoje Uprawlenije Isprawitielno-Trudowych Łagierej, Trudowych Posielenij i Miest Zakljuczenija = GUŁag. 
W tym czasie (1935) dokonano reformy systemu zarządzania obozami, a mianowicie tylko wielkie obozy, realizujące wielkie inwestycje gospodarcze pozostawiono w bezpośrednim zarządzaniu centrali GUŁagu. Były to łagry: Bajkalsko-Amurski, Białomorsko-Bałtycki, Dmitrowski (kanał Moskwa-Wołga), Uchtyjsko-Peczorski (węgiel, ropa i inne), Tiemnikowski (opał z lasów dla Moskwy). Zarządzanie pozostałymi obozami przekazano szefom NKWD na szczeblu terytorialnym ${ }^{7}$.

W apogeum wielkiego terroru, w drugiej połowie lat trzydziestych, do łagrów napływały rzesze skazanych, tych, którzy nie zostali rozstrzelani ${ }^{8}$. W ciągu 10 miesięcy, od 1 czerwca 1937 r. do 1 kwietnia 1938 r. liczba więźniów wzrosła o ponad 800 tys. osób, przekraczając $2 \mathrm{mln}$. Powołano do życia jeszcze wiele innych obozów oraz znacznie rozbudowywano dotychczasowe: niektóre rozrosły się do rozmiaru gigantów, np. Siewwostłag w rejonie Kołymy ${ }^{9}$, ale rekordzistą był Bajkalsko-Amurski ITŁ liczący 1 kwietnia 1938 r. aż 268637 więźniów ${ }^{10}$; takie kolosy z biegiem czasu dzielono, bo zarządzanie przekraczało możliwości.

Nowy (1938) szef NKWD - Ławrientij Pawłowicz Beria - przystąpił do unowocześnienia resortu, w tym także struktur GUŁagu. To już jest jednak historia późniejsza, wykraczająca poza ramy czasowe pamiętnika Czistiakowa.

Jak wcześniej wspomniano, autor pamiętnika, Iwan Pietrowicz Czistiakow, powołany do wojsk wewnętrznych NKWD, skierowany został do Bajkalsko-Amurskiego ITŁ. Warto przybliżyć postać naczelnika Bamłagu, największego z gigantów archipelagu GUŁag, bo krótko wcześniej nowym naczelnikiem (od 19 lutego 1934 r. do 22 maja 1938 r.) został najbardziej sławetny z naczelni-

7 A. Lityński, Prawo Rosji i ZSRR 1917-1991..., s. 369.

8 Liczba rozstrzelanych tylko w 1937 r. wynosiła 353074 osoby. M. Smirnow, S. Sigaczow, D. Szkapow, System miejsc uwięzienia w ZSRR w latach 1929-1960..., s. 39.

9 Kołyma: 1) rzeka w Jakucji i obwodzie magadańskim, uchodząca do Morza Wschodniosyberyjskiego; 2) zespół obozów koncentracyjnych 1932-1960 rozmieszczonych w dorzeczu Kołymy. W dolinie Kołymy znajdują się bogate złoża złota, platyny, uranu, ołowiu i wielu innych. Brak połączenia drogowego z resztą kraju (do 1970), jedyny szlak morski Władywostok-Magadan zimą nieczynny; średnia temperatura zimą minus 40-50 stopni C. W 1932 r. utworzono przedsiębiorstwo „Dalstroj” obsługiwane przez Siewwostłag; rocznie na Kołymę przybywało - według różnych szacunków - od 125 tys. do 500 tys. więźniów. Łagry kołymskie, obok sołowieckich, należały do najcięższych w całym "archipelagu GUŁag”, a śmiertelność w latach czterdziestych wynosiła powyżej 80\%, później znacznie spadła. Wybuch wojny 22 czerwca 1941 r. zagroził w ogóle połączeniu z Władywostokiem, gdyż część trasy morskiej przebiegała przez wody japońskie, dowóz zaś dużej liczby niewolników do pracy był konieczny. Wówczas ogromne tysiące ludzi rzucono do morderczej i zupełnie beznadziejnej pracy przy budowie drogi na Jakutię, by tamtędy uzyskać połączenie z resztą Syberii.

10 M. Smirnow, S. Sigaczow, D. Szkapow, op. cit., s. 39-40. Nieco inne liczby, ale o analogicznej dynamice, podaje S. Ciesielski, GUŁag..., s. 21. 
ków - Naftalij Frenkiel11; chyba można go nazwać główną postacią archipelagu GUŁag; był spiritus movens rozwoju systemu obozowego; niektórzy jemu przypisują wprowadzenie w łagrach zasady - ,jesz tyle, ile pracujesz". Naftalij Frenkiel urodził się w 1883 r. w rodzinie żydowskiego urzędnika w Hajfie (należącej wówczas do Imperium Osmańskiego); nie znamy jego drogi do Rosji, ale był w niej na pewno w 1919 r., a jako agent prywatnej (okres NEP-u) linii żeglugowej na Morzu Czarnym został w 1924 r. skazany na 10 lat łagru za jakieś przestępstwa finansowe (może kontrabandę) i wysłany do najcięższego wówczas miejsca - na Sołówki ${ }^{12}$. W jaki sposób udało mu się przeobrazić z więźnia w naczelnika obozu, pozostaje tajemnicą. Domysły są takie, że być może na piśmie sporządził radykalny plan likwidacji marnotrawstwa i poprawy efektywności ekonomicznej obozu, w którym się znalazł, co miałoby ponoć dotrzeć do samego Gienricha Jagody³, głównego twórcy systemu obozowego. Awanse $\mathrm{z}$ więźnia na strażnika ${ }^{14}$ to były zdarzenia względnie częste

11 Lagry. Przewodnik..., s. 150.

12 Sołowiecki ITŁ, położony na Wielkiej Wyspie Sołowieckiej, w obwodzie archangielskim; używane były też inne nazwy, zwłaszcza Sołowiecki Obóz Robót Przymusowych Specjalnego Przeznaczenia; założony w 1923 r., potem na jego bazie utworzono Białomorsko-Bałtycki ITŁ.

13 Gienrich (Henryk) Grigorjewicz Jagoda (1891-1938), ur. w żydowskiej rodzinie w Łodzi, biografia jego zawiera wyjątkowo dużo białych plam; od 1907 r. w SDPRR(b), 1911-1913 na zesłaniu, uczestnik rewolucji październikowej, od 1920 r. w resorcie bezpieczeństwa, 1924 r. - zastępca szefa OGPU; zły stan zdrowia szefa OGPU Mienżynskiego i jego pasywny styl zarządzania sprawiły, że realna władza przeszła w ręce Jagody; organizator i (1930) szef GUŁagu; następca Mienżynskiego, od 10 lipca 1934 r. ogólnozwiązkowy ludowy komisarz spraw wewnętrznych (NKWD ZSRR); prawdopodobnie na polecenie Stalina zorganizował zabójstwo Kirowa (1934); organizował i realizował pierwsze dwulecie wielkiego terroru stalinowskiego; niezręcznie przygotowany przez niego proces Zinowiewa i Kamieniewa wywołał niezadowolenie Stalina, który po znanej depeszy do Biura Politycznego spowodował usunięcie go (26 września 1936) ze stanowiska ludowego komisarza NKWD; krótko był ludowym komisarzem łączności; w 1937 r. aresztowany; oskarżony m.in. o współpracę z carską Ochraną, wywiadem niemieckim, otrucie Gorkiego i Mienżynskiego, sądzony w głośnym procesie tzw. prawicowo-trockistowskiego bloku antyradzieckiego (wspólnie z Bucharinem i Rykowem), skazany na karę śmierci 13 marca 1938 r. i w tym samym dniu rozstrzelany; żona i siostra zesłane do łagru, kilkuletni syn oddany do domu dziecka. G. Przebinda, J. Smaga, Kto jest kim w Rosji po 1917 roku. Leksykon, Kraków 2000; Leksykon. Rosja, red. W. Sienkiewicz, Warszawa 2001; N. Polmar, T. B. Allen, Księga szpiegów. Encyklopedia, Warszawa 2000.

14 Aleksander Sołżenicyn pisze o jeszcze dalej idącym zjawisku, o tzw. samoochronie: „Już w pierwszych latach po rewolucji wysunięto przecież tezę, że sowieccy więźniowie powinni pilnować się sami, że to ich obowiązek. Nie bez powodzenia zastosowano tę zasadę na Sołówkach, a w znacznie szerszym zakresie - na Kanale Białomorskim i Kanale Wołga-Moskwa: każdy pociotek socjalny, któremu nie chciało się pchać taczek, mógł dostać karabin i obrócić go przeciw własnym towarzyszom. Nie chcemy twierdzić, że była to celowa, szatańska intryga, mająca na celu moralny rozkład rzesz obywatelskich. Jak zawsze w naszej najnowszej, półwiekowej historii - podniosła, promienna teoria i przyziemna zdawkowa podłość przeplotły się w sposób dziwnie naturalny, z łatwością zamieniając się miejscami. Ale z opowieści starych zeków wiadomo, że członkowie tej formacji bardzo srogo sobie poczynali w stosunku do swoich braci, że wyskakiwali ze skóry, aby wyróżnić się na służbie, utrzymać się na swoim psim posterunku, a czasem stare porachunki osobiste załatwiali jednym pociągnięciem cyngla". A. Sołżenicyn, Archipelag GUŁag 1918-1956. Próba dochodzenia literackiego. Autoryzowany przekład z rosyjskiego J. Pomianowski, t. 2 [cz. 3], Warszawa 1990, s. 484. 
w radzieckim systemie, ale awans więźnia Frenkiela na szczyty GUŁagu to zdarzenie niebywałe. Zwolniony z łagru, przyjęty do bezpieki - OGPU, został najpierw szefem zaopatrzenia Sołówek, potem naczelnym kierownikiem robót w zarządzie budowy Białomorsko-Bałtyckiej Drogi Wodnej, następnie - jak wspomniałem - naczelnikiem największego z łagrów-gigantów - Bajkalsko-Amurskiego ITŁ, a później jeszcze pierwszym szefem powstałego w 1940 r. Zarządu Głównego Obozów Budowy Kolei NKWD-MWD ${ }^{15}$ ZSRR, do przejścia na emeryturę w 1947 r. ${ }^{16}$

Nie wiem, czy i jakie wykształcenie miał naczelnik Bamłagu - Frenkiel, ale A. Applebaum podaje, że spośród jedenastu najwyższych szefów całego GUŁagu ZSRR (lata 1930-1960) zaledwie pięciu miało wyższe wykształcenie, trzech zaś tylko szkołę podstawową. Prości strażnicy to nie tylko ludzie prymitywni, ale to na ogół męty społeczne. Aparat administracyjny GUŁagu traktowany był w NKWD jako miejsce zsyłki funkcjonariuszy pod każdym względem najgorszych lub mających jakieś skazy w politycznym życiorysie ${ }^{17}$. Aleksander Sołżenicyn pytał „po prostu: czy dozorca obozowy może w ogóle być zacnym człowiekiem?". I po analizie rozmaitych postaw pisze - co zresztą oczywiste - że niektórzy są źli od początku i taka nieludzka praca im odpowiada, że większość się wdraża, ale jednak dla niektórych „być niezmiennie narzędziem przemocy, bez wytchnienia służyć złu! - to przecież nie każdy potrafi [...] - i dalej już nie możesz tak żyć"18. Do takiej służby trafił, mający właśnie skazy w życiorysie, Iwan Czistiakow, autor pamiętnika, rewelacyjnego przez sam fakt, że taki istnieje. Ale Czistiakow - inteligent z refleksjami - tak żyć nie mógł.

Sam Iwan Czistiakow i jego dziennik drastycznie ukazują nieludzki system radzieckiej rzeczywistości, demaskują akceptowane każdego dnia zbrodnie popełniane zarówno przez strażników, jak i wśród samych więźniów, gdzie rządzą najdziksze prawa dżungli, na co ochrona nie próbuje reagować, bo „dają wyroki za słuszne czy niesłuszne użycie broni, a zekowi za zabójstwo - nic. Cóż, niech tam, niech zeki sami się biją, nie potrzebujemy się mazać ich krwią" (s. 55). Janusz Bardach tak opisywał zbiorowy gwałt na kobietach, na statku wiozącym więźniów na Kołymę: „W nocy aż się wzdrygnąłem, słysząc przeraźliwe krzyki. Dochodziły z dolnych prycz. Głosy kobiet. [...] Spojrzałem na przejście. Przy otworze w ścianie panował ścisk: męż-

15 Ministierstwo wnutriennych dieł - Министерство внутренных дел - Ministerstwo Spraw Wewnętrznych. O przekształceniach organizacyjnych resortu spraw wewnętrznych, w tym bezpieki zob. np. A. Lityński, Prawo Rosji i ZSRR 1917-1991..., s. 335 i nast.

16 Lagry. Przewodnik..., s. 115, 150, 158; zob. także A. Applebaum, op. cit., s. 58 i nast., w tym zob. przypis Redaktorki na s. 59.

17 A. Applebaum, op. cit., s. 254.

18 A. Sołżenicyn, op. cit., s. 462. 
czyźni siłą wyciągali przezeń kobiety jak worki z mąką i porywali ze sobą. Nie wiedziałem, że na statku były też więźniarki; musieli zapewne zapędzić je dopiero po zamknięciu nas w ładowniach. Gdy tylko kobieta wynurzała się przez otwór, mężczyźni natychmiast zdzierali z niej ubranie. Każdą z nich atakowało naraz kilku mężczyzn. Widziałem wijące się białe ciała ofiar, ich rozpaczliwie kopiące nogi, ręce wbijające się niczym szpony w twarze mężczyzn. Kobiety gryzły, krzyczały i płakały. Gwałciciele oddawali razy. [...] Na pryczy leżała ciemnowłosa kobieta, unieruchomiona przez mężczyznę, który przygwoździł każdą jej kończynę. Inni zrzucali spodnie i kolejno wchodzili na nią. Nie przestawała rzucać głową na boki. - Leż spokojnie, ty suko. Zakrztusisz się moim fiutem, jak dalej będziesz wrzeszczeć. - Straciłem rachubę, ile kobiet zniewolono. Krzyki słychać było w coraz odleglejszych zakątkach ładowni. Gdy gwałcicielom zabrakło kobiet, co roślejsi mężczyźni zaczęli polować na młodych chłopaków z prycz i włączali ich do rzezi. Młodzieńcy leżeli nieruchomo na brzuchu na podłodze, krwawiąc i płacząc. $Z$ innych prycz zwisały setki mężczyzn, którzy przyglądali się wydarzeniom, ale ani jeden nie próbował ich przerwać. [...] Na pryczy naprzeciw mnie leżała w kałuży krwi młodziutka kobieta. Jej długie, jasne włosy walały się $\mathrm{w}$ zmierzwionych puklach ponad głową, a udręczonych piersi nie dało się rozpoznać. Ciało kobiety spoczywało zupełnie bez ruchu, miała przymknięte oczy, lecz przez twarz przebiegały mimowolne drgawki, przywodzące na myśl skrzydło konającego ptaka"19.

Badacze tragicznego losu łagierników całkowicie zgodni są co do tego, że przemoc była codziennością życia obozowego, że nadzór faworyzował najgorszych kryminalistów, że dręczenie więźniów i dopuszczanie się wobec nich czynów bestialskich, włącznie $\mathrm{z}$ nieuzasadnionymi zabójstwami, należało do tej codzienności ${ }^{20}$.

Nie tylko od Czistiakowa wiemy, że w łagrze „nawet mord na bezbronnym w żaden sposób nie zakłóci codzienności [...], śmierć stała się niezauważalnym fragmentem tej codzienności" 21 . „[...] będzie trzeba, to rozstrzelamy" - zapisuje w dzienniku Czistiakow (s. 68). Tak się wrasta w system, przygasają ludzkie uczucia, narasta obojętność wobec ludzkich losów. "Jednak wrastam w BAM. Niepostrzeżenie, sytuacja, obyczaje, życie - zasysają. Zresztą zapewne inaczej nie może być" (s. 59). Nawet ci, którzy początkowo byli porządnymi ludźmi, stają się bezduszni, bo są i bezsilni, i osamotnieni, i widzą beznadziejność całej sytuacji, a nad każdym strażnikiem i wyższym funkcjonariuszem GUŁagu też

19 J. Bardach, K. Gleeson, Człowiek człowiekowi wilkiem. Przeżyłem Gułag, tłum. E. E. Nowakowska, Kraków 2002, s. 210-211.

20 S. Ciesielski, Wróg jest wszędzie. Stalinowska polityka represyjna w latach 1928-1941, Torun 2013, s. 288.

21 I. Sariusz-Skąpska, Polscy świadkowie GUŁagu. Literatura łagrowa 1939-1989, wyd. 3, Kraków 2012, s. 321 . 
wisi aresztowanie i zamiana ról. Autorka wprowadzenia, cytowana już Irina Scherbakowa, trafnie napisała, że „dziennik chwilami wydaje się niemal zapiskami samobójcy” (s. 29). Już po pół roku takiej „psiej służby” (Sołżenicyn), z datą 2 maja 1936 r. Czistiakow zapisał: „Tak odmienił mnie BAM. Tak zmienił moje myśli. Uczynił przestępcą. [...] Przygotowuję się i przyzwyczajam do tego, co będzie. A może palnę sobie w łeb? Upłynęły miesiące służby, upłyną następne tak samo jak pierwsze, w smutku i przygnębieniu. A w przyszłości to samo. Oto praca, która prowadzi do przestępstwa. Dusza rwie się na strzępy i ściska się w bólu serce. Przeszłość wydaje mi się snem. Aż nie do wiary, czy ja mieszkałem w Moskwie i na wolności? Planowałem i budowałem życie" (s. 138).

Ten dziennik trzeba po prostu przeczytać.

Ile wart jest człowiek zapytała w swoich wspomnieniach Jefrosinia Kiersnowska, Rosjanka (trochę z polskimi korzeniami) z Besarabii, która spędziła 20 lat w gułagu ${ }^{22}$.

Adam Lityński (Sosnowiec)

22 J. Kiersnowska, Ile wart jest człowiek, tłum. W. Karaczewska, E. Niepokólczycka, E. Rojewska-Olejarczuk, Warszawa 2012. 